\title{
Postveraison Application of Antitranspirant Di-1-p-Menthene to Control Sugar Accumulation in Sangiovese Grapevines
}

\author{
Alberto Palliotti, ${ }^{1}$ Francesco Panara, ${ }^{1}$ Franco Famiani, ${ }^{1}$ Paolo Sabbatini, ${ }^{2}$ \\ G. Stanley Howell, ${ }^{2}$ Oriana Silvestroni, ${ }^{3}$ and Stefano Poni ${ }^{4 *}$
}

\begin{abstract}
The effectiveness of a postveraison application of the film-forming antitranspirant Vapor Gard (VG, a.i. di-1-p-menthene) was investigated as a technique to delay grape ripening and reduce sugar accumulation in the berry. The study was carried out over the 2010-2011 seasons in a nonirrigated vineyard of cv. Sangiovese in central Italy. Vapor Gard was applied at $2 \%$ concentration to the upper two-thirds of the canopy (most functional leaves) and it significantly lowered leaf assimilation and transpiration rates and increased intrinsic water use efficiency. The $\mathrm{F}_{\mathrm{v}} /$ $\mathrm{F}_{\mathrm{m}}$ ratio was not modified, emphasizing that photoinhibition did not occur at the photosystem II complex, whereas the reduction of pool size of plastoquinone matched well with reduced $\mathrm{CO}_{2}$ fixation found in VG-treated vines. In both years VG treatment reduced the pace of sugar accumulation in the berry as compared to control vines, scoring a -1.2 Brix at harvest and wine alcohol content at $-1 \%$ without compromising the recovery of concentrations of carbohydrates and total nitrogen in canes and roots. Concurrently, organic acids, $\mathrm{pH}$, and phenolic richness of grapes and wines were unaffected, whereas there was a decrease in anthocyanin content in the berry (-19\% compared to control vines) and in the wine (-15\% compared to control vines). The application of VG at postveraison above the cluster zone is an effective, simple, and viable technique to hinder berry sugaring and obtain less alcoholic wines. To be effective the spraying should be performed at $\sim 14$ to 15 Brix, making sure that the lower leaf epidermis is fully wetted by the chemical.
\end{abstract}

Key words: berry composition, vine yield, reserve storage, photosynthesis, chlorophyll fluorescence, wine composition

The specific climate is crucial to the overall style of a wine produced from a well-defined area. The ability to reach complete grape maturation is important in determining the best cultivar to be grown in a given climate and climate variability determines year-to-year differences in the grape and wine quality (Jones and Hellman 2003). In particular, temperature and irradiance are critical because of their direct effect on the length of growing season, vine and berry phenological stages, vine yield by means of flower and berry abscission, berry growth, and the synthesis and accumulation of sugars, organic acids, polyphenols, and aromatic compounds in the berries (Gladstones 1992). A steady trend of increased warming is pushing traditional areas of grapegrowing toward accelerated ripening (Jones et al. 2005), leading, in turn, to

${ }^{1}$ Professor, Dipartimento di Scienze Agrarie e Ambientali, Università di Perugia, Borgo XX Giugno 74, 06128 Perugia, Italy; ${ }^{2}$ Professor, Department of Horticulture, Michigan State University, East Lansing, MI, 98824 USA; ${ }^{3}$ Professor, Dipartimento di Scienze Agrarie, Alimentari ed Ambientali, Università Politecnica delle Marche, Via Brecce Bianche, 60131 Ancona, Italy; and ${ }^{4}$ Professor, Istituto di Frutti-Viticoltura, Università Cattolica del Sacro Cuore, Via Emilia Parmense 84, 29100 Piacenza, Italy.

*Corresponding author (email: stefano.poni@unicatt.it; tel: +39-0523-599271; fax: +39-0523-599268)

Acknowledgments: This research was partially funded by the Italian Ministry for University (PRIN 2009 Grant) and Biogard Division (Grassobbio, Italy). The authors are grateful to Drs. Fabrizio Leoni, Riccardo Cini, and Massimo Benuzzi for critical appraisal and helpful discussion.

Manuscript submitted Jan 2013, revised Apr 2013, accepted May 2013

Copyright (C) 2013 by the American Society for Enology and Viticulture. All rights reserved.

doi: 10.5344/ajev.2013.13015 excessive sugar accumulation in the fruit and high alcohol in the wine. Yet climate change and increased variability are thought to contribute to only $50 \%$ of the increase in alcohol levels in wines (Jones 2007). Rising sugar content in grapes and increased alcohol in wines are influenced by other environmental traits and technical choices, including higher potential canopy photosynthesis due to the steady increase of $\mathrm{CO}_{2}$ concentration in the atmosphere (Schultz 2000); improvements in vineyard management and in control strategies of pests and insects; legal yield constraints in several appellation areas; greater use of cultivars genetically characterized by low productivity due to reduced cluster weight and/ or grafted on low vigor rootstocks; and improved sanitary status of propagation material.

While the improvement of sugar accumulation in berries has long been a key objective of viticulture research, the role of sugar concentration has recently undergone a rethinking by researchers. Many consumers now prefer wines with more moderate alcohol content (Seccia and Maggi 2011). It has been shown that ethanol can enhance the perception of sweetness and bitterness while reducing that of acid, saltiness, and sourness (Martin and Pangborn 1970, Fisher and Noble 1994).

Limiting grape sugar concentration in the vineyard is useful to minimize costly interventions in the winery aimed at dealcoholizing wines by up to $-2 \%$ vol, such as membrane techniques, supercritical fluid extraction, and vacuum distillation. These techniques have recently become legal in the European Union (Council Regulation n. 606/2009). Moreover, one negative consequence of a premature Brix development is that in several viticultural areas this process occurs during the hottest part of the season (Jones et al. 2005), when both 
color and aroma profile can be adversely affected (Lacey et al. 1991, Reynolds and Wardle 1993, Mori et al. 2007). Under these conditions, grapes often combine an excessively low acidity and high $\mathrm{pH}$, thus requiring additional cellar costs to balance the must. This action typically involves the addition of tartaric acid before fermentation in order to avoid microbiological instability and improve mouthfeel (Keller 2010).

Among the canopy management techniques which have been tested to regulate sugar accumulation in the berries and/ or modulate accelerated or unbalanced ripening, application of antitranspirant compounds has been interesting for its low cost and ease of application (Palliotti et al. 2012). Antitranspirants have been widely used to counteract drought events since, once applied to leaves, they significantly reduce water loss and heat stress (Gale and Poljakoff-Mayber 1967, Rosati 2007). Depending on the mode of action, there are two types of antitranspirant: film-forming polymers sprayed on leaf surfaces (Gale and Poljakoff-Mayber 1967) and stomataclosing compounds (Zelitch 1969). The second group includes alkenilsuccinic acids, phenylmercuric acetate, abscisic acid, and chitosan ( $\beta$-1,4-D-glucosamine), a deacetylated chitin derivative. The latter compound has been recently proved to be effective in protecting bean leaves from ozone damage (Francini et al. 2011), reducing powdery mildew incidence in grapevine leaves, and improving total polyphenols and antioxidant activity in Montepulciano grapes and wine (Iriti et al. 2011). The film-forming polymer kaolin, an inert clay mineral, was effective at controlling heat stress in several species by increasing canopy reflectance of infrared and ultraviolet radiations, thereby reducing leaf and fruit tissue temperature (Rosati 2007). The effects of kaolin on leaf photosynthesis provide contrasting results, due also to counteractive effects of the antitranspirant on stomatal aperture and gas-exchange especially under water deficit conditions (Davenport et al. 1972, Rosati 2007).

It was recently demonstrated that source limitation during the postveraison stage, through mechanical leaf removal apical to the cluster zone, was able to reduce sugar accumulation in the berry and delay grape Brix accumulation without delaying increases in pigment and phenolic ripening (Palliotti et al. 2013). Source limitation might also be imposed through the use of antitranspirant compounds (Gale and PoljakoffMayber 1967), which have already shown efficacy to reduce gas-exchange in different crop species (Iriti et al. 2009, Francini et al. 2011), including grapevine (Palliotti et al. 2010). Using field-grown Sangiovese vines, a two-year study was conducted to test the effectiveness of a postveraison application of an organic film-forming antitranspirant at delaying sugar accumulation in the berries and to evaluate its effects on vine physiology, wine quality, and replenishment of the storage of reserves in cane wood and roots.

\section{Materials and Methods}

Plant material and experimental layout. The study was carried out over the 2010 and 2011 seasons in a nonirrigated commercial vineyard sited in central Italy near Deruta (Perugia, Umbria region, $42^{\circ} 59^{\prime} \mathrm{N}, 12^{\circ} 25^{\prime} \mathrm{E}$, elev. $405 \mathrm{~m}$ asl, loamy soil type). The vineyard was a 12-year-old planting of Vitis vinifera L. cv. Sangiovese (clone VCR30 grafted onto 420A rootstock) planted at $2.5 \mathrm{~m} \times 1.0 \mathrm{~m}$ inter- and intrarow and trained to a vertically shoot-positioned, spur-pruned cordon trellis with a budload of $\sim 10$ nodes per meter of row length. The cordon was trained $0.9 \mathrm{~m}$ aboveground with three pairs of foliage wires on a canopy wall extending $1.2 \mathrm{~m}$ above the cordon. Pest management was carried out according to local standard practice and shoots were mechanically trimmed when most started to outgrow the top wire.

Four adjacent rows of 60 vines each were selected to create a completely randomized block design with each row as a block. Half of the vines of each block were randomly assigned to antitranspirant Vapor Gard treatment (VG) and the vines of the other half were used as an unsprayed control (C). In 2010 , due to heavy rain occurring one week after the first treatment, VG was applied twice, on 10 and 27 Aug, respectively, whereas in 2011 it was sprayed once, on 18 Aug. Vapor Gard (Intrachem Bio Italia, Grassobbio, Italy) is a water emulsifiable organic concentrate for use on plants designed to reduce transpiration by forming a clear, soft, and flexible film that reduces normal moisture loss. Its active ingredient is di-1- $p$-menthene $\left(\mathrm{C}_{20} \mathrm{H}_{34}\right)$, a therpenic polymer, also known as pinolene, which is produced from resins of conifers by a distillation process. Each year, VG was prepared at $2 \%$ concentration in water, stirred slowly to form an emulsion, and all the leaves of the canopy located above the cluster area were sprayed using a portable pump. The abaxial surfaces of the leaves were wet well in order to cover the stomatal pores.

Leaf gas-exchange and chlorophyll fluorescence. In 2010, beginning one week before spraying, single leaf gas exchange readings were taken on $\mathrm{VG}$ and $\mathrm{C}$ vines at varying intervals until harvest in the morning hours (1000-1100 hr) of clear days using a portable, open system LCA-3 infrared gas analyzer (ADC Bio Scientific, Herts, UK). The system featured a broad leaf chamber with a $6.25 \mathrm{~cm}^{2}$ window, and all readings were taken at ambient relative humidity with an air flow adjusted to $350 \mathrm{~mL} / \mathrm{min}$. Twelve primary leaves per treatment (three replicates per block) were chosen at nodes 8 to 10 above the distal bunch and sampled under saturating light photosynthetic active radiation (PAR $>1400 \mu \mathrm{mol}$ photons $\left.\mathrm{m}^{-2} \mathrm{~s}^{-1}\right)$. Assimilation rate $(\mathrm{A})$, transpiration rate $(\mathrm{E})$, stomatal conductance $\left(\mathrm{g}_{\mathrm{s}}\right)$, and substomatal $\mathrm{CO}_{2}$ concentration $(\mathrm{Ci})$ were calculated from inlet and outlet $\mathrm{CO}_{2}$ and $\mathrm{H}_{2} \mathrm{O}$ concentrations. Intrinsic water use efficiency (WUEi) was then derived as the A to $g_{s}$ ratio. On the same leaves used for the gas exchange readings, temperature was also measured using an infrared thermometer (model TM909L9; Assi-control, Varese, Italy).

To highlight a possible instability of the photochemical apparatus, chlorophyll fluorescence was measured between 1100 and $1200 \mathrm{hr}$ on $16 \mathrm{Aug}$ (a day with very low assimilation rate in VG-treated vines) with a lightweight portable continuous excitation fluorometer (Handy-PEA, Hansatech Instuments, Norfolk, UK). These measurements were performed on the same leaves sampled for gas exchange with the addition of lateral leaves from the same shoots (12 per treatment, three replicates per block, taken in the middle section of lateral 
shoots). Dark adaptation was achieved by covering the sample area to be analyzed with a small, lightweight leaf clip for at least $30 \mathrm{~min}$. The small shutterplate of the clip was then opened and the dark-adapted leaf tissue exposed to an actinic light flash (650 nm wavelength, intensity $>3000 \mu \mathrm{mol} \mathrm{m}^{-2} \mathrm{~s}^{-1}$ ). The instrument provides the $\mathrm{F}_{\mathrm{v}} / \mathrm{F}_{\mathrm{m}}$ ratio, which is a widely accepted indicator of the maximum photochemical efficiency of photosystem II (PSII), where $\mathrm{F}_{\mathrm{m}}$ is the fluorescence maximum over the induction curve. $\mathrm{F}_{\mathrm{v}}$, termed variable fluorescence, was calculated as the difference between $\mathrm{F}_{\mathrm{m}}$ and $\mathrm{F}_{\mathrm{o}}$, where $F_{o}$ is the ground fluorescence (Strasser et al. 1995). The area above the fluorescence curve between $F_{o}$ and $F_{m}$ (Area), which indicates the pool size of plastoquinone on the reducing size of PSII, was also automatically calculated.

Yield component and grape composition. In 2010 and 2011, beginning from VG treatment until harvest, total soluble solids (Brix) was periodically assessed on 180 berry samples (four samples of 45 berries per treatment and measurement date, one replicate per block) using a temperature-compensating refractometer (RX-5000; Atago Ltd., Tokyo, Japan). The rate of Brix accumulation per day was also calculated.

Harvest dates were 27 Sept 2010 and 14 Sept 2011. Grapes from 50 experimental vines per treatment were individually picked, the number of clusters per vine and the crop weight were recorded, and the average cluster weight calculated. Each year, four samples of 300 berries per treatment (one replicate per block) were randomly collected and their fresh weight was recorded. Brix, titratable acidity, and $\mathrm{pH}$ for each sample were analyzed after crushing. Titratable acidity was measured with a Titrex Universal Potentiometric Titrator (Steroglass, Perugia, Italy), titrating with $0.1 \mathrm{~N} \mathrm{NaOH}$ to an end point of $\mathrm{pH} 8.2$. Results were expressed as $\mathrm{g} / \mathrm{L}$ of tartaric acid equivalent. Must $\mathrm{pH}$ was measured using a PHM82 standard $\mathrm{pH}$ meter (Radiometer, Copenhagen, Denmark). Anthocyanin and phenolic contents (expressed as $\mathrm{mg} / \mathrm{cm}^{2}$ skin) were determined on berry skins according to Ough and Amerine (1980) and Slinkard and Singleton (1977), respectively. From each treatment, 2010 $\mathrm{mm}$ diameter disks of the grape skin (five replicates per each block) were cut and carefully separated from the flesh. Disks were taken from the external, middle portion of well-exposed clusters. Each skin disk $\left(0.785 \mathrm{~cm}^{2}\right)$ was macerated in $25 \mathrm{~mL}$ methanol containing $0.1 \% \mathrm{HCl}(\mathrm{v} / \mathrm{v})$ at $\mathrm{pH} 1$ and incubated at room temperature $\left(\sim 25^{\circ} \mathrm{C}\right)$ for $24 \mathrm{hr}$ in the dark with periodic shaking. The total anthocyanin content was determined by measuring the absorbance at $520 \mathrm{~nm}$, without filtration or centrifugation and with no correction for background absorbance, at pH 1 using an extinction coefficient (molar absorbance value) of 28,000 and molecular weight of 529 (typical of malvidin-3-glucoside). Total soluble phenols were assayed as follows: to each $0.2 \mathrm{~mL}$ sample, $1.8 \mathrm{~mL}$ distilled water (diluted to contain 0 to $250 \mathrm{mg} / \mathrm{L}$ gallic acid equivalent) was added and then followed by $10 \mathrm{~mL} 10 \%$ aqueous Folin-Ciocalteau reagent (Sigma) and $8 \mathrm{~mL} 7.5 \%(\mathrm{w} / \mathrm{v})$ aqueous $\mathrm{Na}_{2} \mathrm{CO}_{3}$. The mixture was held at $24^{\circ} \mathrm{C}$ and after $2 \mathrm{hr}$ the absorbance was read at $750 \mathrm{~nm}$ and compared to a gallic acid standard curve. Yeast assimilable nitrogen (YAN) content, including ammonium salts and $\alpha$-amino acids, was estimated according to a method based on the reaction of formaldehyde with amino functions (Masneuf and Dubourdieu 1999).

Microvinification and wine analysis. In 2010 and 2011, wines were made using microvinification techniques. At harvest, grapes from $120 \mathrm{VG}$-treated and $120 \mathrm{C}$ vines were harvested manually and transported to the experimental winery in $20 \mathrm{~kg}$ plastic boxes. For each treatment, the total harvested grape mass was divided into two lots, each weighing $\sim 150 \mathrm{~kg}$. Each lot was mechanically crushed, destemmed, transferred to $100 \mathrm{~L}$ stainless-steel fermentation containers, sulfited with $35 \mathrm{mg} / \mathrm{L} \mathrm{SO}_{2}$, and inoculated with $35 \mathrm{mg} / \mathrm{L}$ of a commercial yeast strain (Lalvin EC-1118; Lallemand, Montreal, Canada). Wines were fermented for 16 to 18 days on the skin and punched down twice daily, with the fermentation temperature ranging from 20 to $27^{\circ} \mathrm{C}$. After alcoholic fermentation, the wines were pressed at 0 Brix and inoculated with $30 \mathrm{mg} / \mathrm{L}$ Oenococcus oeni (Lalvin Elios 1 MBR; Lallemand). After completion of malolactic fermentation, the samples were racked and transferred to $60 \mathrm{~L}$ steel containers and $25 \mathrm{mg} / \mathrm{L}$ $\mathrm{SO}_{2}$ was added. Two months later, the wines were racked again, bottled into $750 \mathrm{~mL}$ bottles, and then closed with cork stoppers. After eight months, the wines were analyzed for alcohol, titratable acidity, and pH (Iland et al. 1993). Wine color intensity $\left(\mathrm{OD}_{420}+\mathrm{OD}_{520}\right)$, color hue $\left(\mathrm{OD}_{420} / \mathrm{OD}_{520}\right)$, and total phenol and anthocyanin concentrations were determined with a spectrophotometer. Total phenols were quantified according to Ribéreau-Gayon (1970) by measuring the absorbance at $280 \mathrm{~nm}$ of wine diluted 1:100 with distilled water. Anthocyanins were analyzed as reported by Ribéreau-Gayon and Stonestreet (1965). All determinations were carried out in duplicate, yielding four replicates per treatment.

Carbohydrates and nitrogen storage in permanent vine organs. At the end of December 2010 and 2011, the soluble sugars and starch concentrations in canes (node 3 ) and roots (fine brown, $1.5 \pm 0.2 \mathrm{~mm}$ diam, taken at 10 to $20 \mathrm{~cm}$ soil depths) were determined on six replicates per treatment according to a colorimetric method (Loewus 1952) using anthrone reagent (Merck, Darmstadt, Germany). Absorbance readings at $620 \mathrm{~nm}$ wavelength were performed on a Jasco V-630 spectrophotometer (Tokyo, Japan). Total nitrogen concentration was determined on the same material using a Kjeldahl method.

Statistical analysis. Two-way analysis of variance (ANOVA) was used to assess treatment and year effects on yield components, grape and wine composition, and reserves storage in canes and roots using SigmaStat 3.5 software package (Systat Software, San Jose, CA). Mean separation was performed by Student-Newman-Keuls test $(p \leq 0.05)$. Unless a significant year $\times$ VG treatment interaction occurred, values are presented as means pooled over years. Seasonal evolution of gas exchange parameters, chlorophyll fluorescence, and soluble solids are shown as means \pm standard error.

\section{Results}

Heat accumulation expressed as growing degree days (GDD, base $10^{\circ} \mathrm{C}$ ) from $1 \mathrm{Apr}$ to $30 \mathrm{Sept}$ was quite similar in 2010 (170 GDD) and 2011 (1849 GDD. The rainfall summation 
over the same period was lower in 2011 (232 mm) than in 2010 (366 mm). In both years, no visual symptoms of water stress or significant leaf yellowing were observed and no new leaves developed from primary or lateral shoots after treatment.

One week after VG treatment, the sprayed leaves showed a great reduction in leaf assimilation (A) and transpiration rate $(\mathrm{E})$ (Figure $1 \mathrm{~B}, \mathrm{C})$ followed by a rapid recovery of $\mathrm{A}$ and $\mathrm{E}$ to levels similar to those of control leaves. The rapid recovery was likely the result of heavy rain recorded on 16

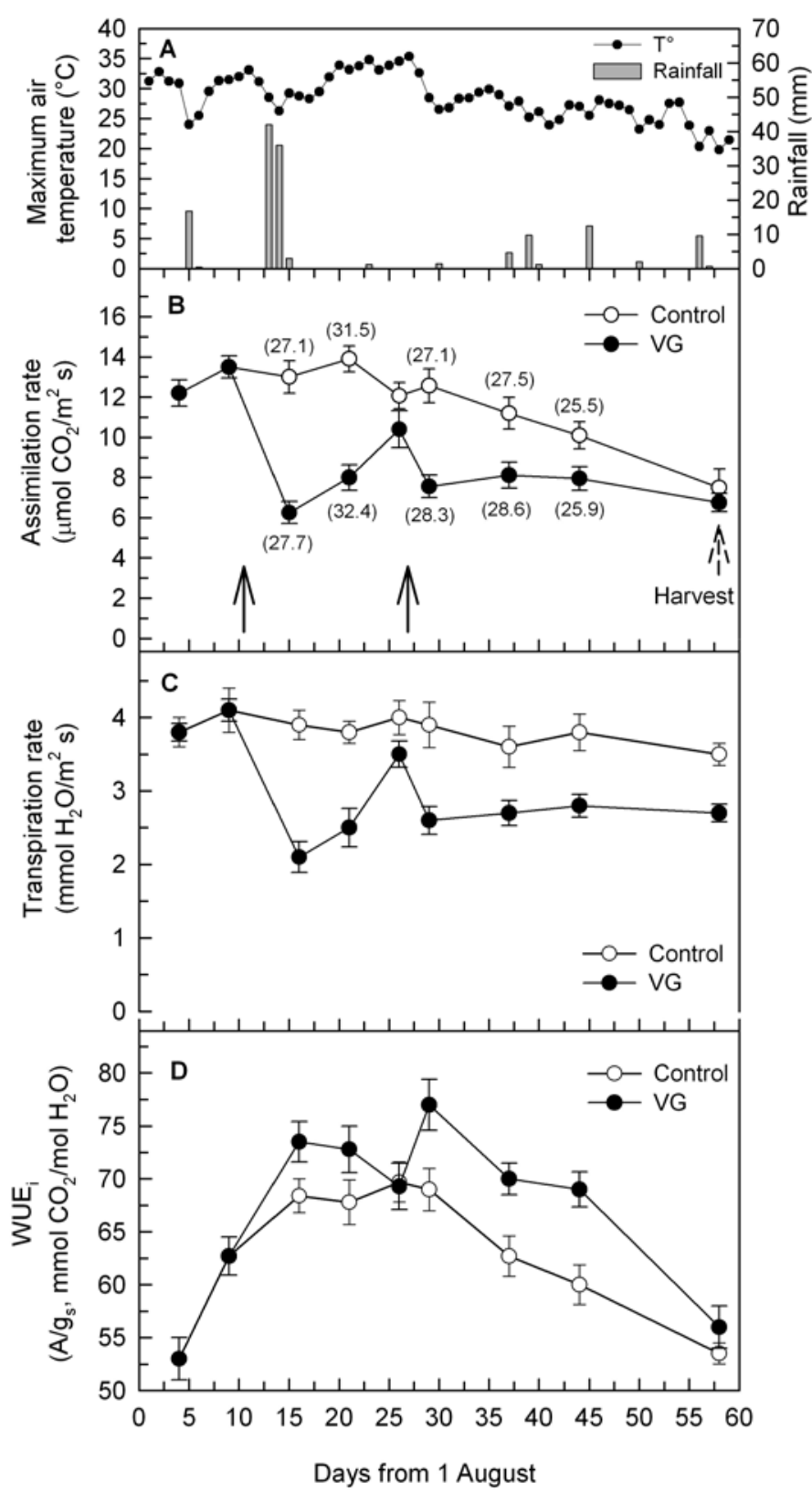

Figure 1 Seasonal trends of maximum air temperature and rainfall (A), assimilation rate (B), transpiration rate (C), and intrinsic water use efficiency (D) (WUEi calculated as assimilation/stomatal conductance ratio) recorded in 2010 on fully expanded median Sangiovese primary leaves sprayed twice with antitranspirant Vapor Gard (VG) at $2 \%$ or untreated control. Bold arrows indicate the time of VG application. Data are mean \pm SE $(n=12)$. In $B$, values between brackets are mean leaf temperatures recorded with an infrared thermometer concurrently with gas exchange readings. and 17 Aug (42 and $36 \mathrm{~mm}$, respectively) (Figure 1A). After the second VG application, A and E rates again decreased, demonstrating the effectiveness of $\mathrm{VG}$ in rapidly reducing stomatal opening upon treatment. Thereafter, the capacity for carbon gain of VG-treated leaves remained limited for a period of four weeks until harvest, when A again converged toward levels seen in C leaves (Figure 1B). Conversely, at harvest, sprayed leaves still had lower E than control leaves (Figure 1C). The depression of E after VG application resulted in a significant increase of WUEi in VG relative to $\mathrm{C}$ vines (Figure 1D) and was of similar duration, suggesting a lower water loss in VG relative to $\mathrm{C}$ vines, while both achieved a similar carbon gain. Moreover, leaf temperature was not significantly modified by the VG treatment within the 1000 to $1100 \mathrm{hr}$ window (Figure 1B).

For chlorophyll fluorescence parameters, the $\mathrm{F}_{\mathrm{v}} / \mathrm{F}_{\mathrm{m}}$ ratio measured in both primary and lateral leaves did not show any difference between treatments (Figure 2); whereas the area parameter, which defines the pool size of plastoquinone, the primary electron acceptor on the reducing side of PSII, showed a significant reduction in VG primary and lateral leaves.

Regardless of year, VG applied postveraison above the cluster zone did not affect yield per vine or average cluster and berry weight (Table 1). Similarly, no statistical difference was found in titratable acidity, must $\mathrm{pH}$, total phenolics, and YAN between treatments, whereas in the VG-treated vines, Brix and the anthocyanin content were significantly reduced by $\sim 1.2$ Brix and $\sim 19 \%$, respectively, as compared to $C$ vines.

Dynamics of berry Brix showed that, regardless of season, accumulation slowed about 10 days after VG treatment

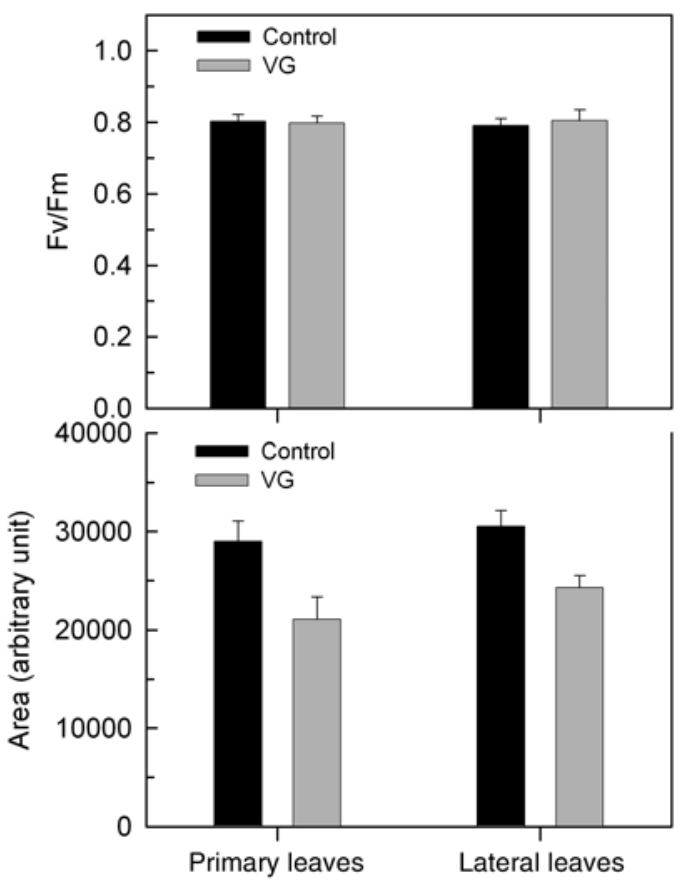

Figure 2 Maximal photochemical efficiency of PSII $\left(F_{v} / F_{m}\right)$ and the pool size of plastoquinone on reducing size of PSII (Area) recorded in 2010 on median primary and lateral leaves of Sangiovese vines sprayed twice with antitranspirant Vapor Gard (VG) at $2 \%$ or untreated control. Data are mean \pm SE $(n=20)$. 
(Figure 3). Berry fresh weight for VG-treated vines did not change as compared to $\mathrm{C}$ vines in either year. The reduction in Brix found in VG-treated vines seems linked to impaired canopy photosynthetic capacity and/or limitation in sugar translocation from leaves to berries. Between VG application and harvest, the rate of Brix accumulation in the berries decreased from $0.31 \mathrm{Brix} / \mathrm{day}$ in $\mathrm{C}$ vines to $0.27 \mathrm{Brix} /$ day in VGtreated vines in 2010 and from $0.29 \mathrm{Brix} /$ day in the $\mathrm{C}$ vines to $0.23 \mathrm{Brix} /$ day in VG-treated vines (Figure 3). At 2010 harvest, a reduction of $33 \mathrm{mg}$ soluble solids per berry was assessed in VG-treated vines compared to $\mathrm{C}$ vines, while in 2011 this limitation was equal to $\sim 20 \mathrm{mg} /$ berry.

Wines made from grapes of VG-treated vines after one year of aging had a $1 \%$ lower alcohol content than wines made from grapes of $\mathrm{C}$ vines, while titratable acidity, $\mathrm{pH}$, total dry extract, and phenolics including tannins were similar (Table 2). The concentration of anthocyanin was instead significantly reduced in the VG-treated wines (-15\%); consequently, the chromatic intensity of the wines was lowered, but without measurable variation in the color hue.

Samples taken at the end of December and analyzed for the alcohol-soluble sugars, starch, and total nitrogen stored in the stems and roots showed no concentration differences between treatments and years (Table 3 ).

\section{Discussion}

The antitranspirant VG applied at postveraison on the most functional leaves, namely fully expanded median and apical leaves from either primary or lateral shoots located above the cluster zone, significantly lowered leaf assimilation and transpiration rates and optimized WUEi. In 2010, heavy rain occurring soon after the first treatment likely caused premature wash-off of the chemical and the spray

\begin{tabular}{|c|c|c|c|c|c|c|}
\hline \multirow[b]{2}{*}{ Parameter } & \multicolumn{3}{|c|}{ Treatment $^{a}$} & \multicolumn{3}{|c|}{ Year $^{a}$} \\
\hline & C & VG & $\overline{\text { Sig }}$ & 2010 & 2011 & Sig \\
\hline Nodes retained (n/vine) & 9.3 & 9.9 & ns & 9.6 & 9.5 & ns \\
\hline Clusters (n/vine) & 10.0 & 10.5 & ns & 11.0 & 9.8 & ns \\
\hline Yield/vine (kg) & 3.21 & 3.16 & ns & 3.34 & 3.12 & ns \\
\hline Cluster wt (g) & 324 & 305 & ns & 306 & 318 & ns \\
\hline Berry wt (g) & 2.32 & 2.29 & ns & 2.19 & 2.37 & ns \\
\hline Total soluble solids (Brix) & $24.0 \mathrm{a}$ & $22.8 \mathrm{~b}$ & * & 22.8 & 23.3 & ns \\
\hline Titratable acidity (g/L) & 6.5 & 6.2 & ns & 6.5 & 6.3 & ns \\
\hline Must pH & 3.37 & 3.34 & ns & 3.28 & 3.36 & ns \\
\hline $\begin{array}{l}\text { Anthocyanins } \\
\text { (mg/cm² skin) }\end{array}$ & $0.381 \mathrm{a}$ & $0.308 \mathrm{~b}$ & * & 0.345 & 0.325 & ns \\
\hline $\begin{array}{l}\text { Total phenols } \\
\text { ( } \mathrm{mg} / \mathrm{cm}^{2} \text { skin) }\end{array}$ & 0.775 & 0.698 & ns & 0.751 & 0.714 & ns \\
\hline YAN (mg/L) ${ }^{b}$ & 124 & 123 & ns & 138 & 109 & ns \\
\hline
\end{tabular}

${ }^{a}$ Means within rows denoted by different letters are significantly different by the Student-Newman-Keuls test. *, ns indicate significance at $p \leq 0.05$ or not significant, respectively.

bYeast-assimilable nitrogen content including ammonium salts and $\alpha$-amino acids. had to be repeated 10 days later. As the reduction of stomatal conductance $\left(\mathrm{g}_{\mathrm{s}}\right), \mathrm{A}$, and $\mathrm{E}$ rates following VG spraying was accompanied by a marked reduction (from 60 to $70 \%$ compared to leaves of control vines) of substomatal $\mathrm{CO}_{2}$ concentration (182 to $218 \mathrm{ppm}$ in control leaves versus 112 to 165 ppm in VG-treated leaves), it is apparent that this behavior was linked to some physical impairment of stomatal opening and function. The fact that the film-forming VG exerts a physical barrier to gas exchange, thus hampering the $\mathrm{CO}_{2}$ entering the stomata and the water vapor leaving the stomata, was found almost 40 years ago on Vicia faba by Davenport et al. (1972), who also noted that under the transparent film the stomata were more open. Scanning electron micrographs on bean plants (Iriti et al. 2009) confirmed these results. Moreover, in peach, midday leaf water potential increased after an antitranspirant application as compared to unsprayed plants (Davenport et al. 1972). Thus, maintenance of high moisture of the leaf tissue in conjunction with possible effects of light reflectance might explain why treated leaves did not heat up significantly, in agreement with findings in a tropical plant using the same compound (Moftah and AlHumaid 2005). In terms of light reflectance, VG behaves differently than kaolin-based foliar reflectants, which have proven to cause a significant reduction of leaf and/or berry temperature (Moftah and Al-Humaid 2005, Rosati 2007, Shellie and King 2013), especially under limiting water supply. At the same time, the $\mathrm{F}_{\mathrm{v}} / \mathrm{F}_{\mathrm{m}}$ ratio was not modified,

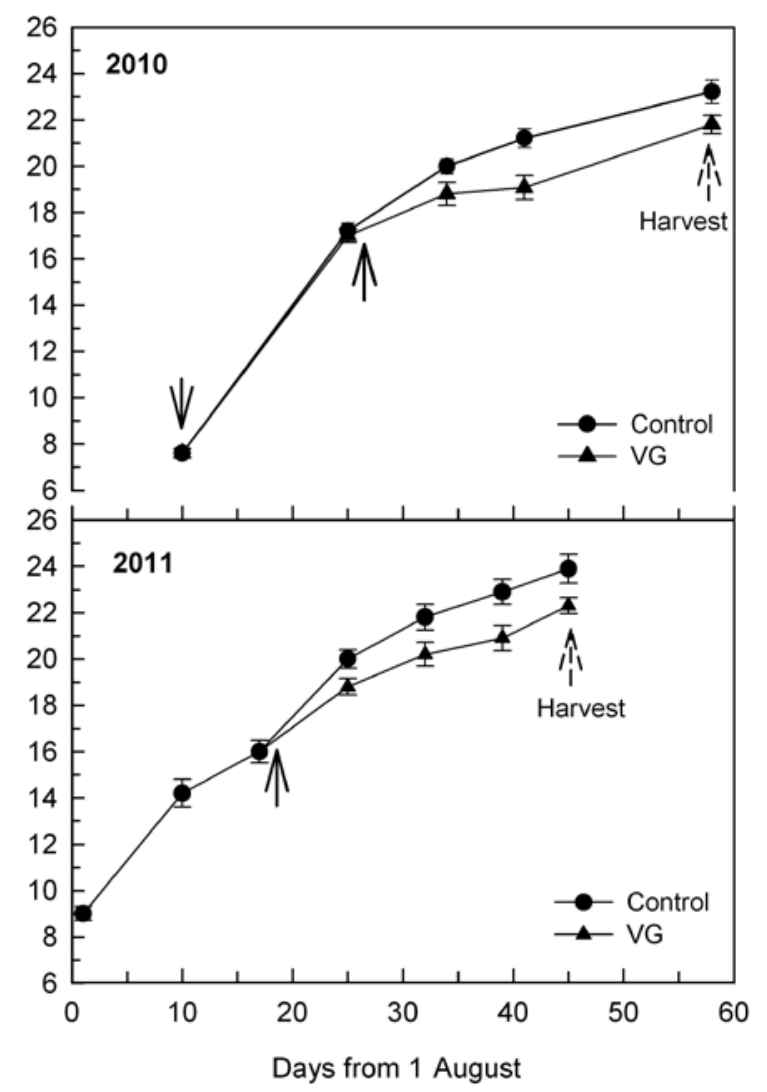

Figure 3 Seasonal trends of total soluble solids content recorded in 2010 and 2011 on Sangiovese vines treated in postveraison with antitranspirant Vapor Gard $(V G)$ at $2 \%$ or untreated control. Data are mean $\pm S E(n=6)$. 
emphasizing that photoinhibition did not occur at the PSII complex, while the observed reduction of the plastoquinone pool size complements a parallel reduction of the capacity of VG-treated vines to fix $\mathrm{CO}_{2}$.

The significant improvement of intrinsic WUEi, extending from the time of VG application until the final stage of ripening, indicates a lower water loss through stomata for a similar carbon gain. This behavior occurred because the limitation in stomatal conductance of $\mathrm{H}_{2} \mathrm{O}$ was proportionally higher than the depression of its assimilation rate.

A significant source limitation following VG spraying has been previously assessed in different species (Iriti et al. 2009, Francini et al. 2011), including grapevine (Palliotti et al. 2010) and, quite remarkably, the above source limitation is reached without modifying the vine leaf-to-fruit ratio or the cluster microclimate during ripening. This strategy of canopy management, applied late in the season, has been effective

Table 2 Wine composition recorded over 2010-2011 vintages from Sangiovese vines treated in postveraison with antitranspirant Vapor Gard (VG) or control (C). Data averaged over treatments and years in the absence of significant interactions. Wines were analyzed one year after alcoholic fermentation in both years.

\begin{tabular}{|c|c|c|c|c|c|c|}
\hline \multirow[b]{2}{*}{ Parameter } & \multicolumn{3}{|c|}{ Treatment $^{\mathrm{a}}$} & \multicolumn{3}{|c|}{ Year $^{\mathrm{a}}$} \\
\hline & C & VG & Sig & 2010 & 2011 & Sig \\
\hline Alcohol (\% v/v) & $14.3 \mathrm{a}$ & $13.3 b$ & * & 13.0 & 13.4 & ns \\
\hline Titratable acidity (g/L) & 6.05 & 5.60 & ns & 6.12 & 6.01 & ns \\
\hline $\mathrm{pH}$ & 3.47 & 3.56 & ns & 3.40 & 3.52 & ns \\
\hline Total dry extract (g/L) & 22.8 & 21.6 & ns & 21.6 & 22.5 & ns \\
\hline Anthocyanins (g/L) & $0.218 a$ & $0.185 b$ & * & 0.194 & 0.215 & ns \\
\hline Total phenolics (g/L) & 1.53 & 1.42 & ns & 1.51 & 1.48 & ns \\
\hline Total tannins (g/L) & 1.04 & 1.01 & ns & 1.11 & 1.15 & ns \\
\hline $\begin{array}{l}\text { Color intensity } \\
\left(\mathrm{OD}_{420 \mathrm{~nm}}+\mathrm{OD}_{520 \mathrm{~nm}}\right)\end{array}$ & $9.2 \mathrm{a}$ & $6.1 \mathrm{~b}$ & * & 8.1 & 7.9 & ns \\
\hline $\begin{array}{l}\text { Color hue } \\
\left(\mathrm{OD}_{420 \mathrm{~nm}} / \mathrm{OD}_{520 \mathrm{~nm}}\right)\end{array}$ & 0.67 & 0.73 & ns & 0.68 & 0.71 & ns \\
\hline
\end{tabular}

aMeans within rows denoted by different letters are significantly different by the Student-Newman-Keuls test. *, ns indicate significance at $p \leq 0.05$ or not significant, respectively.

Table 3 Cane wood and root reserves recorded in Sangiovese vines treated in postveraison with antitranspirant (VG) or control (C). Data averaged over treatment and year in the absence of significant interactions.

\begin{tabular}{|c|c|c|c|c|c|c|}
\hline \multirow[b]{2}{*}{ Parameter } & \multicolumn{3}{|c|}{ Treatment $^{\mathrm{a}}$} & \multicolumn{3}{|c|}{ Year $^{\mathrm{a}}$} \\
\hline & $\mathbf{C}$ & VG & Sig & 2010 & 2011 & Sig \\
\hline \multicolumn{7}{|l|}{ Cane wood } \\
\hline Total nitrogen $(\% \mathrm{dw})$ & 0.48 & 0.53 & ns & 0.59 & 0.42 & ns \\
\hline $\begin{array}{l}\text { Alcohol soluble sugars } \\
\text { (mg/g dw) }\end{array}$ & 229.0 & 213.9 & ns & 209.7 & 243.0 & ns \\
\hline Starch $(\mathrm{mg} / \mathrm{g} \mathrm{dw})$ & 59.0 & 55.8 & ns & 53.8 & 61.0 & ns \\
\hline \multicolumn{7}{|l|}{ Root } \\
\hline Total nitrogen (\% dw) & 0.78 & 0.80 & ns & 0.88 & 0.71 & ns \\
\hline $\begin{array}{l}\text { Alcohol soluble sugars } \\
(\mathrm{mg} / \mathrm{g} \mathrm{dw})\end{array}$ & 120.7 & 132.4 & ns & 120.7 & 132.5 & ns \\
\hline Starch $(\mathrm{mg} / \mathrm{g} \mathrm{dw})$ & 193.2 & 177.8 & ns & 178.6 & 192.0 & ns \\
\hline
\end{tabular}

${ }^{a}$ ns: not significant. in reducing the pace of sugar accumulation in the berry, as compared to control vines, scoring a -1.2 Brix at harvest and lowering the alcohol content in the resulting wines by $-1 \%$ vol. It can be recommended as a valuable cultural practice in viticultural areas where berry ripening takes place early during the hottest part of the season. In such a context, maturation is often associated with hot periods leading to an accelerated ripening process; $\mathrm{pH}$ and sugar concentration rise too high, yet doing so with a still unfinished or atypical phenolic and aromatic profile, requiring grapes to hang longer on the canopy. For red grape cultivars, a premature harvest cannot, obviously, be proposed. Poor phenolic and aromatic maturity would increase the likelihood of higher extractability of proanthocyanidins from seeds, which, in turn, would lead to wines with excessive grassy and bitter tastes. In the absence of atypical phenolics, grassy flavors, bitter tastes, and unusual aromatic compounds in berries and wines, we can state that the VG treatment does not produce effects similar to those of "premature harvest."

The removal of basal leaves is a common practice used to improve grape composition and health, and improvements of anthocyanin content in the berry and in wine quality after late defoliation were reported (Hunter et al. 1991). While high temperatures tend to accelerate grape ripening, too much heat leads to symptoms of berry shrivelling and sunburn, through excessive water loss and protein denaturation, respectively, as well as impairment of grape and wine color and aromatic intensity (Lacey et al. 1991, Reynolds and Wardle 1993, Spayd et al. 2002, Mori et al. 2007). Therefore, in all areas where an increase of temperature during ripening is now likely, basal leaf removal cannot be applied without serious risk of lowering the quality of the grapes, including the aromatic potential due to a reduction of methoxypyrazine accumulation (Lacey et al. 1991, Scheiner et al. 2010) as well as the accumulation of terpenes (Belancic et al. 1997).

The late season source limitation induced by VG treatment proved to be effective, regardless of season, in delaying Brix accumulation in the berries without compromising the replenishment of the concentration of reserves in storage organs. We speculate that the photosynthesis recovery from just before until after harvest has probably been sufficient to replenish the cane and root reserves of soluble sugars and starch. Depending on weather conditions, in central Italy leaves can retain a good photosynthetic rate up to 60 to 70 days after harvest.

Notably, the reduction of Brix accumulation in the berry achieved with VG treatment occurred without significant detriment to the accumulation of phenolic compounds while berry pigmentation was lowered. Regarding the latter, usually anthocyanins are negatively influenced by high temperature and overheating (Spayd et al. 2002). A recent article reported that color accumulation in Sangiovese was least when full leaf removal was applied, while it improved when some leaf cover around the clusters was maintained (Kotseridis et al. 2012). Our experimental approach did not alter the microclimate around the fruiting zone since no leaves were removed. Consequently, the reduction of color may 
be linked to a down-regulation of the expression of genes involved in the synthesis of phenylalanine-ammonia-lyase (PAL), a key enzyme engaged in phenylpropanoid and flavonoid biosynthetic pathways, following a strong reduction of the source:sink ratio after VG application. Recently, this enzyme and the galactinol synthase, an important regulator of carbon partitioning, were strongly up-regulated after application of a cluster-thinning treatment, which caused a sharp increase in the source:sink balance (Pastore et al. 2011). On the other hand, it was found that in red grapes the sugar content could regulate the synthesis and accumulation of anthocyanins (Pirie and Mullins 1976), and, likewise, an increase of PAL activity and accumulation of anthocyanins were noted after treatments with sucrose and other sugars (Roubelakis-Angelakis and Kliewer 1986, Vitrac et al. 2000).

Moreover, since the stomata under the film formed by VG application remain open (Davenport et al. 1972, Iriti et al. 2009), it is conceivable that the turgor of fruit cells remains high, which may cause a decrease in sugar influx and ABA and which, in turn, could deactivate the expression of sugar transporters and anthocyanin pathway genes. In grapes it has been demonstrated that exogenous ABA application increased the expression of genes coding for anthocyanin synthesizing enzymes (Jeong et al. 2004) and activated invertase enhancing the accumulation of glucose and fructose (Pan et al. 2005). Iriti et al. (2009) reported a drastic reduction of ABA in VG treated as compared to untreated bean leaves $(0.058$ versus $0.218 \mathrm{mg} / \mathrm{g}$ ).

The reduction of anthocyanins assessed in VG-treated vines is certainly undesirable if the wines are intended for aging, but would be acceptable for young, rosé, or base wines to be used for blending with dark wines. Indeed, Sangiovese is used to produce wines such as Brunello di Montalcino, Nobile di Montepulciano, and Chianti, but it is also widely used for the production of light table wines, where a loss of 15 to $20 \%$ grape anthocyanins is not a problem. In cultivar naturally rich in extractable anthocyanins $(>1 \mathrm{~g} / \mathrm{kg})$, such as Teroldego, Lagrein, Enantio, Rebo, Marzemino, Croatina, Syrah, Merlot, and Montepulciano, a 15 to $20 \%$ loss of anthocyanins is quite sustainable.

\section{Conclusion}

The application of the organic film-forming antitranspirant, Vapor Gard, to Sangiovese vines postveraison and above the cluster zone is a suitable strategy to delay ripening in the berry as compared to nontreated vines. The method proved to be effective and easy to apply to hinder berry sugaring and to obtain lower alcohol wines. Concurrently, apart from the 15 to $20 \%$ loss of anthocyanins, this method had no other negative impact on phenolic compounds, organic acids, or $\mathrm{pH}$ in grape and wines or on the replenishment of the concentration of carbohydrates in canes and roots under the conditions of this trial. To be effective in reducing the accumulation of total soluble solids in the berries, the Vapor Gard emulsion should be applied above the cluster zone at 14 to 15 Brix and should completely wet the lower leaf surface where stomata are located.

\section{Literature Cited}

Belancic, A., E. Agosin, A. Ibacache, E. Bordeu, R. Baumes, A. Razungles, and C. Bayonove. 1997. Influence of sun exposure on the aromatic composition of Chilean Muscat grape cultivars Moscatel de Alejandría and Moscatel rosada. Am. J. Enol. Vitic. 48:181-186.

Davenport, D.C., M.A. Fisher, and R.M. Hagan. 1972. Some counteractive effects of antitranspirant. Plant Physiol. 49:722-724.

Fischer, U., and A.C. Noble. 1994. The effect of ethanol, catechin concentration, and $\mathrm{pH}$ on sourness and bitterness of wine. Am. J. Enol. Vitic. 45:6-10.

Francini, A., G. Lorenzini, and C. Nali. 2011. The antitranspirant di1 - $p$-menthene, a potential chemical protectant of ozone damage to plants. Water Air Soil Pollut. 219:459-472.

Gale, J., and A. Poljakoff-Mayber. 1967. Plastic films on plants as antitranspirants. Science 156:650-652.

Gladstone, J. 1992. Viticulture and Environment. Winetitles, Adelaide, Australia.

Hunter, J.J., O.T. De Villiers, and J.E. Watts. 1991. The effect of partial defoliation on quality characteristics of Vitis vinifera L. cv. Cabernet Sauvignon grapes. II. Skin color, skin sugar, and wine quality. Am. J. Enol. Vitic. 42:13-18.

Iland, P.G., A.J.W. Ewart, and J.H. Sitters. 1993. Techniques for Chemical Analysis and Stability Tests of Grape Juice and Wine. Kitchener Press, Adelaide.

Iriti, M., V. Picchi, M. Rossoni, S. Gomarasca, N. Ludwig, M. Gargano, and F. Faoro. 2009. Chitosan antitranspirant activity is due to abscisic acid-dependent stomatal closure. Environ. Exp. Bot. 66:493-500.

Iriti, M., S. Vitalini, G. Di Tommaso, S. D'Amico, M. Borgo, and F. Faoro. 2011. New chitosan formulation prevents grapevine powdery mildew infection and improves polyphenol content and free radical scavenging activity of grape and wine. Aust. J. Grape Wine Res. $17: 263-269$.

Jeong, S.T., N. Goto-Yamamoto, S. Kobayashi, and M. Esaka. 2004. Effects of plant hormones and shading on the accumulation of anthocyanins and the expression of anthocyanin biosynthetic genes in grape berry skins. Plant Sci. 167:247-252.

Jones, G.V. 2007. Climate change: Observations, projections, and general implications for viticulture and wine production. Working paper no. 7. Whitman College Economic Department, Walla Walla, WA.

Jones, G.V., and E. Hellman. 2003. Site assessment. In Oregon Viticulture. 5th ed. E. Hellman (ed.), pp. 44-50. Oregon State University Press, Corvallis.

Jones, G.V., M.A. White, O.R. Cooper, and K. Storchmann. 2005. Climate change and global wine quality. Climatic Chan. 73:319-343.

Keller, M. 2010. Managing grapevines to optimize fruit development in a challenging environment: A climate change primer for viticulturists. Aust. J. Grape Wine Res. 16:56-69.

Kotseridis, Y., A. Georgiadou, P. Tikos, S. Kallithraka, and S. Koundouras. 2012. Effects of post-flowering leaf removal on berry growth and composition of three red Vitis vinifera $\mathrm{L}$. cultivars grown under semiarid conditions. J. Agric Food Chem. 60:6000-6010.

Lacey, M.J., M.S. Allen, R.L.N. Harris, and W.V. Brown. 1991. Methoxypyrazines in Sauvignon blanc grapes and wines. Am. J. Enol. Vitic. 42:103-108

Loewus, F.A. 1952. Improvement in anthrone method for determination of carbohydrates. Anal. Chem. 24:219.

Martin, S., and R.M. Pangborn. 1970. Taste interaction of ethyl alcohol with sweet, salty, sour and bitter compounds. J. Sci. Food Agric. 21:653-655.

Masneuf, I., and D. Dubourdieu. 1999. L'azote assimilable: Intérêt de son dosage par formoltitration; étude de quelques paraméters à 
l'origine des variations de sa teneur dans les moûts. Rev. Fr. Enol. 93:31.

Moftah, A.E., and A.R.I. Al-Humaid. 2005. Effects of antitranspirants on water relations and photosynthetic rate of cultivated tropical plant (Polianthes tuberosa L.). Pol. J. Ecol. 53:165-175.

Mori, K., N. Goto-Yamamoto, M. Kitayama, and K. Hashizume. 2007. Loss of anthocyanins in red-wine under high temperature. J. Exp. Bot. 58:1935-1945.

Ough, C.S., and M.A. Amerine. 1980. Grape pigments. In Methods for Analysis of Musts and Wines, pp. 206-212. Wiley \& Sons, New York.

Palliotti, A., S. Poni, J.G. Berrios, and F. Bernizzoni. 2010. Vine performance and grape composition as affected by early-source limitation induced with anti-transpirants in two red Vitis vinifera L. cultivars. Aust. J. Grape Wine Res. 16:426-433.

Palliotti, A., O. Silvestroni, F. Leoni, and S. Poni. 2012. Maturazione dell'uva e gestione della chioma in Vitis vinifera: Processi e tecniche da riconsiderare in funzione del cambiamento del clima e delle nuove esigenze del mercato. Italus Hortus 19:1-15.

Palliotti, A., F. Panara, O. Silvestroni, V. Lanari, P. Sabbatini, G.S. Howell, M. Gatti, and S. Poni. 2013. Influence of mechanical postveraison leaf removal apical to the cluster zone on delay of fruit ripening in Sangiovese (Vitis vinifera L.) grapevines. Aust. J. Grape Wine Res. DOI: 10.1111/ajgw.12033.

Pan, Q.H., M.J. Li, C.C. Peng, N. Zhang, X. Zou, K.Q. Zou, X.L. Wang, X.C. Yu, X.F. Wang, and D.P. Zhang. 2005. Abscisic acid activates acid invertases in developing grape berry. Physiol. Plant. 125:157-170.

Pastore, C., S. Zenoni, G.B. Tornielli, G. Allegro, S. Dal Santo, G. Valentini, C. Intrieri, M. Pezzotti, and I. Filippetti. 2011. Increasing the source/sink ratio in Vitis vinifera (cv. Sangiovese) induces extensive transcriptome reprogramming and modifies berry ripening. BMC Genomics 12:631-654.

Pirie, A., and M.G. Mullins. 1976. Changes in anthocyanin and phenolic content of grapevine leaf and fruit tissues treated with sucrose, nitrate, and abscisic acid. Plant Physiol. 58:468-472.

Reynolds, A.G., and D.A. Wardle. 1993. Significance of viticultural and enological practices on monoterpene flavorants of British Columbiagrown Vitis vinifera berries and juices. Wein Wissen. 48:194-202.
Ribéreau-Gayon, P., and E. Stonestreet. 1965. Le dosage des anthocyanes dans le vin rouge. Bull. Soc. Chim. Fr. 9:2649-2652.

Ribéreau-Gayon, P. 1970. Les dosage des composes phénoliques totaux dans le vins rouge. Chimie Anal. 52:627-631.

Rosati, A. 2007. Physiological effects of kaolin particle film technology: A review. Funct. Plant Sci. Biotech. 1:100-105.

Roubelakis-Angelakis, K.A., and W.M. Kliewer. 1986. Effects of exogenous factors on phenylalanine ammonia-lyase activity and accumulation of anthocyanins and total phenolics in grape berries. Am. J. Enol. Vitic. 37:275-280.

Scheiner, J.J., G.L. Sacks, B. Pan, S. Ennahli, L. Tarlton, A. Wise, S.D. Lerch, and J.E. Vanden Heuvel. 2010. Impact of severity and timing of basal leaf removal on 3-isobutyl-2-methoxypyrazine concentrations in red winegrapes. Am. J. Enol. Vitic. 61:358-364.

Schultz, H.R. 2000. Climate changes and viticulture: A European perspective on climatology, carbon dioxide, and UV-B effects. Aust. J. Grape Wine Res. 6:2-12.

Seccia, A., and G. Maggi. 2011. Futuro roseo per i vini a bassa gradazione alcolica. Inf. Agr. (supp.) 13:11-14.

Shellie, K.C., and B.A. King. 2013. Kaolin particle film and water deficit influence Malbec leaf and berry temperature, pigments, and photosynthesis. Am. J. Enol. Vitic. 64:223-230.

Slinkard, K., and V.L. Singleton. 1977. Total phenol analysis: Automation and comparison with manual methods. Am. J. Enol. Vitic. 28:49-55

Spayd, S.E., J.M. Tarara, D.L. Mee, and J.C. Ferguson. 2002. Separation of sunlight and temperature effects on the composition of Vitis vinifera cv. Merlot berries. Am. J. Enol. Vitic. 53:171-182.

Strasser, R.J., A. Srivastava, and Govindjee. 1995. Polyphasic chlorophyll $a$ fluorescence transient in plants and cyanobacteria. Photochem. Photobiol. 61:32-42.

Vitrac, X., F. Larronde, S. Krisa, A. Decendit, G. Deffeux, and J.M. Mérillon. 2000. Sugar sensing and $\mathrm{Ca}^{2+}$-calmodulin requirement in Vitis vinifera cells producing anthocyanins. Phytochemistry 53:659-665.

Zelitch, I. 1969. Stomatal control. Ann. Rev. Plant Physiol. 20:329-350. 